\title{
SIMULTANEOUS OPTIMIZATION OF ELECTRICAL INTERCONNECTION CONFIGURATION IN ONSHORE WIND FIELDS
}

\author{
Maja Celeska, Aleksandra Krkoleva, Krste Najdenkoski, Vladimir Dimčev, Vlatko Stoilkov \\ Faculty of Electrical Engineering and Information Technologies, \\ "Ss. Cyril and Methodius" University in Skopje, \\ Rugjer Bošković bb, P.O. box 574, 1001 Skopje, N. Macedonia \\ celeska@feit.ukim.edu.mk
}

\begin{abstract}
A b s t r a c t: The electrical interconnection cost of onshore wind fields (WF) is a part that should not be neglected in the design of WF. In order to minimize the investment and operational costs, this paper proposes an optimization formulation to find the optimal electrical interconnection configuration of wind turbines (WTs), simultaneously. This simultaneous minimization of total trenching length is done during a WF layout optimization by application of evolutional algorithm. In this paper, an algorithm is considered to comprehensively assess the optimal interconnection layout of the WTs. The interconnections are considerable fraction of the overall design cost of the WF. The optimal electrical interconnection design obtained by an algorithm with implemented Euclidean Minimum Spanning Tree method, corresponds to a lower cost and coupled with the technological developments can help policy makers and WF developers increase the use of onshore wind energy as a feasible unlimited renewable source of electrical energy.
\end{abstract}

Key words: electrical interconnection; onshore wind field; wind turbines; wind energy

\section{ЕДНОВРЕМЕНА ОПТИМИЗАЦИЈА НА ЕЛЕКТРИЧНИТЕ ИНТЕРКОНЕКСИИ КАЈ КОПНЕНИ ВЕТЕРНИ ПОЛИЬА}

\begin{abstract}
А п с т р а к т: При проектирање на едно ветерно поле, аспект кој секако дека не треба да се занемари се електричните интерконексии помеѓу ветерните турбини. Во трудот се предложува алгоритам за изнаоѓање на оптимална конфигурација на електрична интерконекција на ветерни турбини за да се намалат инвестициските и оперативните трошоци. Оваа оптимизасија се одвива едновремено и симултано во склоп на евристички алгоритам за оптимален распоред на ветерни турбини во склоп на едно копнено ветерно поле. Електричните интерконексии имаат значителен удел во вкупните трошоци за изведба на едно ветерно поле. Методот кој е користен за избор на најкратка електрична конексија помеѓу ветерните турбини за конкретна конфигурација на распоредот во ветерното поле е Евклидовата минимална покривка. Алгоритамот се стреми кон избор на најниска цена при оптимизацијата и во комбинација со технолошкиот развој може да е од голема помош за раководни лица и проектанти на ветерни полиња за приказ на ветерот како реално искористлив, а сепак неограничен обновлив извор на електрична енергија.
\end{abstract}

Клучни зборови: електрични интерконексии; копнено ветерно поле; ветерни турбини; ветерна енергија

\section{INTRODUCTION}

The development of windy fields for comercial utilization, globally, it is a considerable challenge for today's wind power industry. An integrated solution to this challenge can only be realized with a high level of synergy between the key elements in 
designing a single WF: selecting the type of turbines, selecting microlocations for setting WTs, and the variability of the natural resource on which it depends the full performance of the WF. According to a Wind Europe report [1], it is assumed that the total installed capacity for wind energy utilization by 2030 in the European Union will be $323 \mathrm{GW}$, of which $253 \mathrm{GW}$ onshore WFs and $70 \mathrm{GW}$ for offshore ones. That would be almost twice the capacity installed by the end of 2017 (168.7 GW), [2]. With this value of total installed power, from the wind energy $888 \mathrm{TWh}$ of electrical energy will be produced, which is equivalent to $30 \%$ of the electricity demand within the European Union.

WF layout concerning various parameters is a major point in planning and will influence the revenue for the whole life of the installation. Besides the obvious impact of wind distribution, also other parameters like connection costs and levelized costs of energy, influence the optimal layout and have to be included in a realistic optimization algorithm. In this paper, the optimal electrical interconnection within an onshore WF is found simultaneously as a part of a heuristic algorithms for finding the optimal WF layout. The developed method is expected to minimize the capital expenditure (CAPEX) of the AC electrical interconnection system. The main contributions of this paper are as follows: use high performance algorithm to solve the formulated discrete optimization problem, without the need for any clustering method; detection and avoidance of cable crossing and provision of a useful tool to find the optimal interconnection layout of one onshore WF with any given topology.

\section{CASE STUDY}

As a rule, connecting any power plant to an interconnected electrical grid requires a voltage level in $\mathrm{kV}$ that lies in the range of the nominal power of the power plant in MW. Thus, a $50 \mathrm{MW}$ power plant would require a minimum voltage level of $50 \mathrm{kV}$. In Macedonia, three different voltage levels are used for transmission: $110 \mathrm{kV}, 220 \mathrm{kV}$ and $400 \mathrm{kV}$. A voltage level of $69 \mathrm{kV}$, widely used in other European countries, is not used in the Macedonian transmission system. WF Bogdanci is established in two phases. Phase one consists of 16 turbines from the same type - SIEMENS SWT-2,3-93 (80 m hub height). In the second phase, another 6 turbines are in plan for positioning. The power plant covers a total area of approx. 10 ha although only approx. 4 ha are used permanently for the operation of the WF (equivalent to $40 \%$ of the total area of the site).
Therefore, the WF Bogdanci with a maximum installed capacity of $50.6 \mathrm{MW}$ has to be connected to the next substation by means of a $110 \mathrm{kV}$ overhead transmission line (OHTL). While there is also the theoretical possibility to have this connection via underground cable-considering the $\sim 12 \mathrm{~km}$ distance to the next substation - this is not a valid option, due to construction costs being more than 3 times higher than that of overhead power lines [3].

Individual WTs of WFs are generally connected by means of underground cables. In some countries, due to lower investment costs, overhead transmission lines are also used (e.g. India), but no European country uses this method. The standard voltage level for the internal cabling of WFs is 20 $\mathrm{kV}$. Higher voltage levels can be selected, but have considerably higher costs. Lower voltages $(10 \mathrm{kV}$, $12 \mathrm{kV}, 13.8 \mathrm{kV}$ etc.) are also possible, but are not recommended as they cause higher line losses. Figure 1 shows the single line diagram for the internal grid connection of the WF. Each turbine has its own $0.69 / 20 \mathrm{kV} / \mathrm{kV}$ transformer. In this case, to avoid overloading the underground cables, a maximum of 4 WTs $(4 \times 2.3=9.2 \mathrm{MW})$ are connected to a single feeder (XHE-49A, $150 \mathrm{~mm}^{2}$ ). Six of the feeders are connected to the bus bar of the wind park substation [4]. Important to mention is that the wind park area covers elevations of between 280 and $500 \mathrm{~m}$ above sea level.

When planning an onshore WF under complex orography conditions, special attention should be applied for determining the location of the substation. The substation itself and the way the WF is connected to the existing power system are an item estimated at $7-10 \%$ of the total capital costs. What is important when modelling a WF is the fact that the substation with its complete equipment needs to be positioned on a surface with a completely flat terrain. In the optimization algorithms developed for this paper, the location of the substation can be determined in two ways: randomly, due to the inability to retrieve the topographic data in the software where the algorithms are developed or predefined according to a given coordinates. Having in mind the abovementioned elevation variations of the terrain, substation's position it is not a design variable in the developed model. The substation's position is defined in advance. Each solution for positioning the WTs is then tested with a short additional module in the algorithms, to determine the shortest paths to installing the cable electrical connections between the turbines and the substation. This segment has been developed to characterize the impact the WF schedule has on final capital expenditures. It 
should be considered that in a more detailed analysis of such an optimization process, the aim would not be to select only the shortest path for electrical con- nections, but also the appropriate voltage level depending on the amount of electricity to be delivered to the substation.

\section{Bogdanci A - Basic Grid Connection Concept}

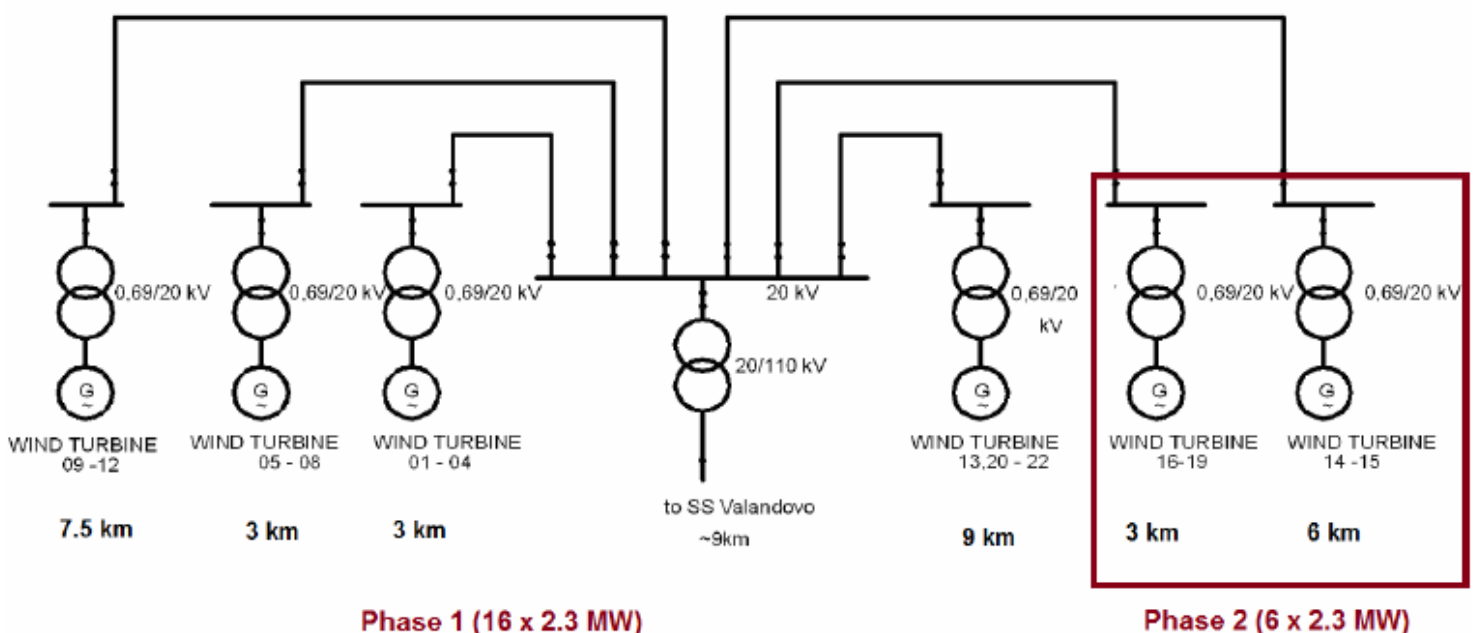

Fig. 1. Single line diagram of the internal grid connection in WF Bogdanci [4]

\section{PROBLEM DESCRIPTION}

For integration of all WTs, during the evolutionary optimization process the WTs could be clustered randomly according to the maximum ampacity of the largest cable dimension, with different shapes and sizes in any iteration. Note that, no specific clustering method is applied before solving the optimization problem. Thereby, in this complex optimization problem, only a small difference may occur between fitness values of the global optimal and local solutions, where it may change the shape and size of clusters as well as the corresponding cable dimension of several paths [5].

Therefore, escaping from local optimum solutions and finding the global optimal solution would be very difficult in a large problem, even with metaheuristic optimization algorithms. In fact, including the cable costs into the objective function creates variable cost branches for each individual solution, thus a complex, non-convex and non-linear optimization problem is formed [6].

The method used to select the shortest electrical connection between WTs for a particular WF layout configuration is the Euclidean Minimum Spanning Tree (EMST) [7]. The EMST method is incorporated in two metaheuristic algorithms - particle swarm algorithm and genetic algorithm in this paper for optimal calculation of the minimum cable length necessary to connect each WTs in a distinct
WF configuration. It is computed by the first constructing the complete graph on the set of points that represent the WTs and edge costs given by the Euclidean distance between any pair of turbines. The minimum spanning tree for this graph is computed and used as an objective representing the costs of the cable length.

According to some studies, the total cost of electrical interconnections can reach a value in the range of $15-30 \%$ of the total investment costs $[8,9]$. For this reason, when analyzing the optimization process for WT positioning from an electro-technical point of view, optimizing the electrical connections between the turbines is an important part not only to reduce investment costs but also in terms of reducing power losses in the WF.

Before developing the appropriate short optimization algorithm for these needs, the following assumptions are made:

- All electrical interconnections between the WTs and the substation will be underground.

- The capacity of all connections is known in advance.

- The cost of the electrical connection increases proportionally with increasing length. The proportion is made up of a percentage share and its transformation into unit sizes.

- Each WT on average has the same production, given the small territorial distribution of the $\mathrm{WF}$, and this is taken as a per unit. 


\section{MATHEMATICAL FORMULATION}

In general, path finding can be described as a specific case of a shortest path tree traversal. The shortest path of a graph can be mathematically formulated as: subject to

$$
\operatorname{minimize} \sum_{i \in A} \sum_{j \in A} d_{i, j} \cdot u_{i, j}
$$

$$
\begin{gathered}
\sum_{i:(i, k) \in V} u_{i, k}-\sum_{j:(k, j) \in A} u_{k, j}= \\
=\left\{\begin{array}{c}
-1, \text { if } k=p_{1} \\
1, \text { if } k=p_{2} \\
0, \text { if }\left(k \in A: k \notin\left\{p_{1}, p_{2}\right\}\right.
\end{array}\right. \\
u_{i, j} \in[0,1] \quad \forall(i, j) \in A .
\end{gathered}
$$

where $u_{i, j}$ is a binary variable describing the connectivity between points $i$ and $j$ in space $A$ in the shortest path. This variable is 1 if $i$ and $j$ are connected in the shortest path and 0 otherwise. The points $p_{I}$ and $p_{2}$ represent the source and termination points respectively and are also with the space $A$. The cost of connecting points $i$ and $j$ (the length of the edge connecting $i$ and $j$ ) is given by $d_{i, j}[10]$.

Let $V$ be a set of $n$ points (sites) in the plane. The Euclidean minimum spanning tree of $V$, $\operatorname{EMST}(\mathrm{V})$, is the minimum spanning tree of the complete graph $G$ on $V$, where the edges are weighted by the Euclidean distance between their endpoints. We assume that $V$ is in general position, i.e. the edge lengths in $G$ are pairwise distinct, thus EMST(V) is unique. Given $V$, we can compute EMST(V) in $O(n \log n)$ time using $O(n)$ words of workspace [11]. Given $n$ sites in the plane, their EMST is the minimum spanning tree with the sites as vertices, where the weight of the edge between two sites is their Euclidean distance [12, 13, 14].

In the limited workspace model as is the WF area, relative neighborhood graph (RNG), cannot be stored explicitly. That is why a complete computation was done for the next batch of edges, whenever there was a need of new edges of RNG(V) in Kruskal's algorithm. To check whether a new edge $e_{i}$ belongs to $\operatorname{EMST}(\mathrm{V}), e_{i}$ is being checked if connects two distinct components of RNGi. To do this with $O(s)$ words of workspace, a succinct representation of its component structure was used. In the developed algorithm, we represent each edge $e_{i}$ by two directed half-edges [12]. The two half-edges are oriented in opposite directions such that the face incident a half-edge lies to the left of it. The endpoints of a half-edge are called the head and the tail such that the half-edge is directed from the tail endpoint to the head endpoint. Obviously, each half-edge in RNGi has an opposing partner.

For $j \geq I \geq 1$, predecessor and successor of $e_{j}$ are defined in RNGi regarding each endpoint $w$ of $e_{j}$ as follows: the predecessor of $e_{j}$ is the half-edge in RNGi which has $w$ as its head and is the first halfedge encountered in a counterclockwise sweep from $e_{j}$ around $w$ [15]. The successor of $e_{j}$ is the half-edge in RNGi which has $w$ as its tail and is the first halfedge encountered in a clockwise sweep from $e_{j}$ around $w$, as shown in Figure 2.

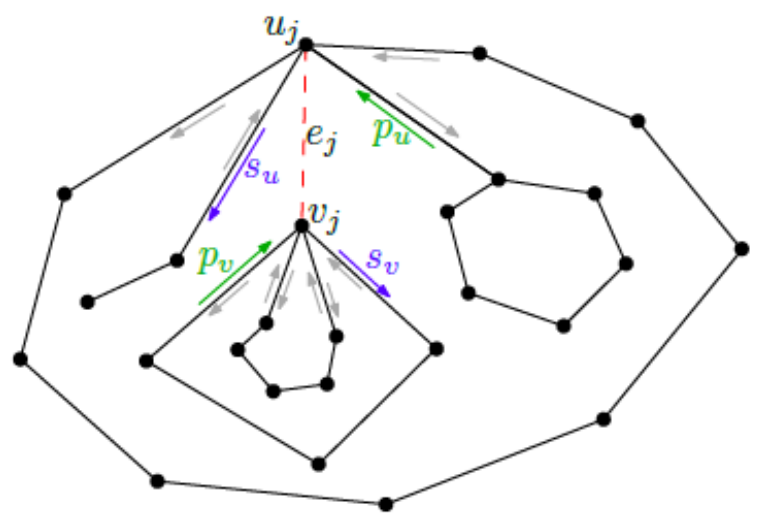

Fig. 2. A schematic drawing of RNGi is shown in black

The endpoint $w=u ; v$ of $e_{j}$ identifies the halfedges $p_{w}$ and $s_{w}$ as the predecessor and the successor of $e_{j}$. They are shown in green and blue, respectively [12].

This general formulation, however, represents the optimization problem once a graph representing the configurational space, the traversable space in which cables can be laid, has been constructed [10].

\section{METHODOLOGY}

Each WT micro-location is represented in a two-dimensional Cartesian coordinate system and they are practically the nodes in the graph. Based on the specified pair of points, the complete graph with all Euclidean distances between each pair of nodes is constructed. Then, based on the value of the equidistant distance, the branches of the graph with the largest weighting factors, i.e. the longest links, are discarded. The calculation of the minimum path when connecting the nodes in this graph is used as a fitness function, which should reduce the cost of electrical interconnections. Figure 3 shows part of the process for finding the final connected graph according to EMST. 


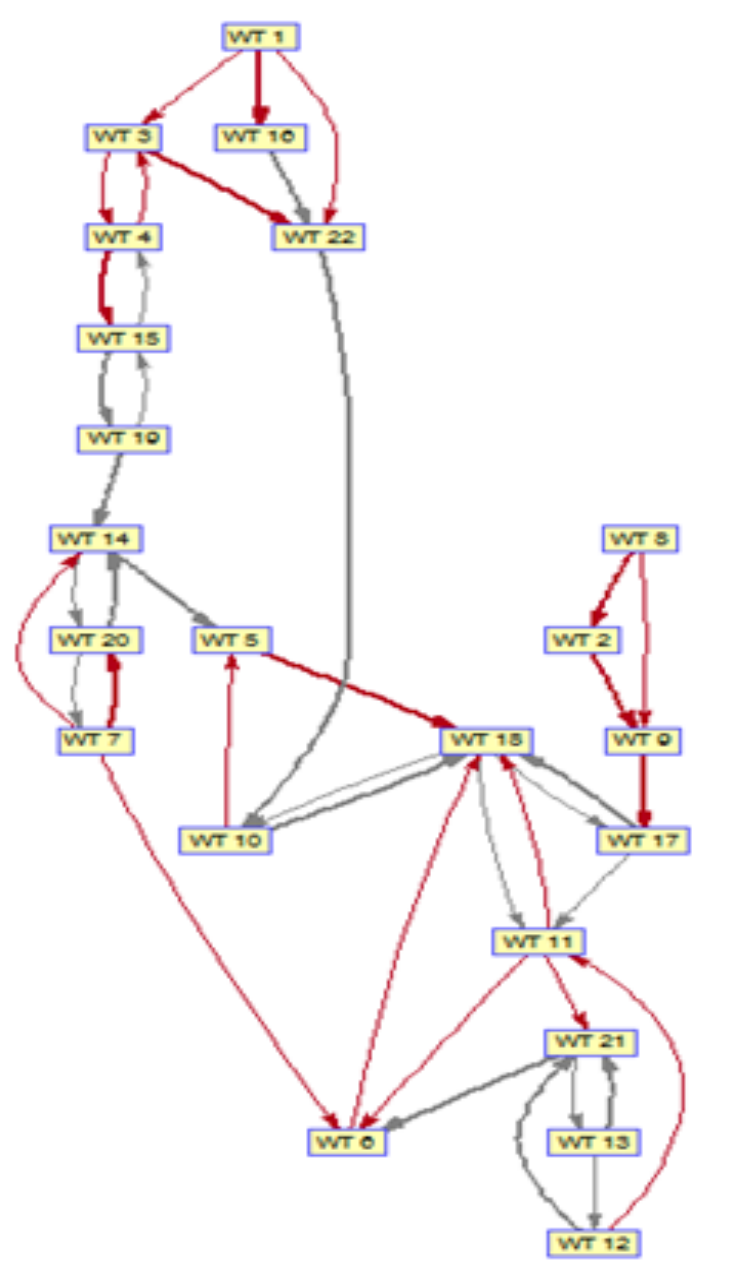

Fig. 3. Appearance of the search process of the shortest turbine connection using EMST

It should be emphasized that when selecting the shortest path, attention is paid to the flow of electricity throughout the entire WF configuration. This type of algorithm, where one observes the flow of nodes, is called a directed algorithm, as described mathematically in the previous section.

The proposed full methodology does, however, successfully place WTs acceptable locations and designs a cable layout that does not violate any of the defined constraints.

The purpose of the developed model is to reduce the total cost of the investment by reducing the electrical connections between the WTs that need to collect the energy produced by each WT and deliver it to the substation dimensioned for the specific WF. Of course, the share of such optimization is not striking, but it is noticeable when comparing the economic benefits of minimizing the total cost of cables. It is also reasonable to expect that the optimal solution will provide a simple but reliable design for a network of cables connecting WTs to each other.

\section{RESULTS AND DISCUSSION}

This simultaneous optimization is solved offline, relying on the mixed-discrete particle swarm optimization algorithm (MD-PSO) as well as nondominated sorting genetic algorithm (NSGA). Each algorithm is run 100 to 1000 times to avoid the uncertainty of the metaheuristic algorithms and calculates their performances. In order to compare the performances of these two algorithms correctly, the stopping criteria of both algorithms set to individual maximum number of iteration so that only running times of the algorithms are relatively similar. This is because the number of generated offspring in any iteration of NSGA is much higher than in the MDPSO algorithm (only one offspring). In order to evaluate the average performances of the NSGA and MD-PSO algorithms in different ranges of WTs, the optimal solutions of both cable sizing methods are calculated for various topologies of WFs - one range with 16 WTs and other with 22 WTs.

The results confirm the better performance of the MD-PSO algorithm to find the global optimal solution of this complex optimization problem, compared to the NSGA. This is because the new harmony (new solution) in the MD-PSO algorithm is improvised with a random selection for each optimization variable individually, by considering all existing solutions in MD-PSO. On the contrary, the NSGA only considers the two parent chromosomessolutions with single- or multi-point crossover. However, the NSGA simulation would be more compatible and perform well for partial cable sizing method, where multipoint crossover is considered; even its performance was relatively close to the MD-PSO algorithm or even better in some particular topologies. Because, in the partial cable sizing method, the cable dimensions of all branches in each route are the same and assigned only according to the ampacity of the last branch before joining to another route. On contrary, according to individual improvising of each optimization variable in the MD-PSO algorithm, it shows more compatibility with full cable sizing rather than partial cable sizing method.

Additionally, the MD-PSO algorithm has found the optimal solution by considering all possible node connections (even non-feasible ones) in the decision set. Yet, due to increased number of iterations to find global optimal solution of a larger problem, each optimization process takes much longer and apparently with lower performance. The fact that, full optimization yields identical results as the 
reduced optimization problem, verifies the functionality of the proposed reduction sub-algorithm.

\section{CONCLUSION}

This article presents a new approach for the inter-array cable design problem for an onshore WF by improving several sub-problems. These subproblems have included a location-constrained, a navigational mesh-based path finding algorithm to determine possible cable connections and two separate modes of operation: binary and continuous mode to solve EMST and select which cable connections should be installed.

This paper proposes an optimization methodology to minimize the capital investment expenditures of the electrical interconnection system of onshore WFs, in order to help designers to reach the necessary balance between technical performance and economic costs. The simultaneous optimization of electrical interconnection configuration and cable sizing of a given onshore WF topology is found. An MD-PSO algorithm as a high-performance optimization algorithm for discrete and continuous problems is used to solve this complex optimization problem. The optimization results are compared with an integer-based NSGA as a proven optimization algorithm. The results demonstrate slightly better performance of the MD-PSO algorithm in comparison with the NSGA, in continuous mode.

A typical radial configuration is also compared with these two optimal layouts. The results illustrate that variation in the WT's power rating completely changes the optimal interconnection layout of one onshore WF. In addition, it turns out that increasing the shipping and burying costs, affects in increasing the CAPEX and often changes the optimal electrical interconnection layout.

The results of such approach applied to a real onshore WF currently in the planning stages have yielded promising results indicating that this approach is not only valid but shows improvements over commonly used approaches based on the turbine separation distance. There is still space for improvements that could be done, but this approach, using EMST method, represents a strong step forward to the efficient automation of the layout design of a WF and optimizing all aspects of the layout.

In the future work, the proposed methodology could be similarly developed to offshore WFs as well.

\section{REFERENCES}

[1] Wind energy in Europe: Scenarios for 2030, Wind Europe, September 2017.

[2] Wind in power 2017 - Annual combined onshore, Wind Europe, February 2018.

[3] Celeska, M., Najdenkoski, K., Dimčev, V., Stoilkov, V.: Equivalent wind farm power curve estimation, Journal of Electrical Engineering and Information Technologies, Vol. 2, No. 2, pp. 105-111 (2017).

[4] Wind Park Development Project Macedonia - Feasibility Study Bogdanci A (The European Union's CARDS Programme for the Western Balkans), WYG International, June 2011.

[5] Yong, C., Kaihua, Z., Zhiwei, Z., Saisong, Y., Hanlu, X., Yang, L.: Optimization of electric system for offshore wind farm based on lightweight substation, Conf. Series: Earth and Environmental Science. Vol. 186, pp. 12-23 (2018).

[6] Sedighi, M., Moradzadhen, M., Kukrer, O., Fahrioglu, M.: Simultaneous optimization of electrical interconnection configuration and cable sizing in offshore wind farms, Journal of Modern Power Systems and Clean Energy, Vol. 6 (4), pp. 749-762 (2018).

[7] Wu, T. R., J., Denison, C., Ackling, T., Wagner, M., Neumann, F.: Fast and effective multi-objective optimisation of wind turbine placement, In: Proceedings of the 15th Annual Conference on Genetic and Evolutionary Computation, July 2013.

[8] Gonzalez, J. S., Payan, M. B., Santos, J. M. R., Logatt, F. G.: A review and recent developments in the optimal windturbine micro-siting problem, Renewable and Sustainable Energy Reviews, Vol. 30, pp. 133-144 (2014).

[9] Hertz, A., Marcotte, O., Mdimagh, A., Carreau, M., Welt, F.: Optimizing the design of a wind farm collection network, Information Systems and Operational Research INFOR, Vol. 50, no. 2, pp. 95-104 (2012).

[10] Pillai, A, Chick, J, Johanning, L, Khorasanchi, M., De Laleu, V.: Offshore Wind Farm Electrical Cable Layout Optimization, Engineering Optimization, 2015. DOI: 10.1080/0305215X.2014.992892

[11] De Berg, M., Cheong, O., Van Kreveld, M., Overmars, M. H.: Computational Geometry: Algorithms and Applications. Springer-Verlag, Third edition, 2008.

[12] Banyassady, B., Barba, L., Mulzer, W.: Time-space tradeoffs for computing Euclidean minimum spanning trees, Computer Science - Coputational Geometry, arXiv:1712.06431v2 [cs.CG] 22 Dec 2017.

[13] Bahoo, Y., Banyassady, B., Bose, P., Durocher, S., Mulzer, W.: Time-space trade-off for finding the $k$-visibility region of a point in a polygon, In: Proc. 11th Workshop Alg. Comp. (WALCOM), Springer-Verlag, 2017, pp. 308319.

[14] Barba, L., Korman, M., Langerman, S., Sadakane, K., Silveira, R. I.: Space time trade-offs for stack-based algorithms, Algorithmica, 72 (4), pp. 1097-1129 (2015).

[15] Darwish, O., Elmasry, A.: Optimal time-space tradeoff for the 2nd convex-hull problem, In: Proc. 22nd Annu. European Sympos. Algorithms (ESA), 2014, pp. 284-295. 